\title{
Insulin resistance and endothelial function are improved after folate and vitamin B12 therapy in patients with metabolic syndrome: relationship between homocysteine levels and hyperinsulinemia
}

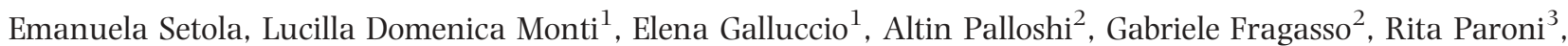
Fulvio Magni ${ }^{4}$, Emilia Paola Sandoli ${ }^{1}$, Pietro Lucotti, Sabrina Costa ${ }^{1}$, Isabella Fermo ${ }^{3}$, Marzia Galli-Kienle ${ }^{4}$, Anna Origgi, Alberto Margonato ${ }^{2}$ and PierMarco Piatti

Cardiovascular and Metabolic Rehabilitation Unit, Rehabilitation and Functional Reeducation Division, ${ }^{1}$ Laboratory L20, Core Laboratory, Diabetology, Endocrinology, Metabolic Disease Unit, ${ }^{2}$ Clinical Cardiology Unit, Cardiothoracic and Vascular Department, ${ }^{3}$ Department of Laboratory Medicine, Scientific Institute H. San Raffaele and ${ }^{4}$ University of Milano-Bicocca, Faculty of Medicine, Milan, Italy

(Correspondence should be addressed to PM Piatti, Cardiovascular and Metabolic Rehabilitation Unit, Via Olgettina 60, 20132 Milano, Italy; Email: piermarco.piatti@hsr.it)

\begin{abstract}
Objective: The purpose of this study was (a) to study whether a folate and vitamin B12 treatment, aimed at decreasing homocysteine levels, might ameliorate insulin resistance and endothelial dysfunction in patients with metabolic syndrome according to the National Cholesterol Education Program-Adult Treatment Panel-III criteria and (b) to evaluate whether, under these metabolic conditions, there is a relationship between hyperhomocysteinemia and insulin resistance.

Design and methods: A double-blind, parallel, identical placebo-drug, randomized study was performed for 2 months in 50 patients. Patients were randomly allocated to two groups. In group 1, patients were treated with diet plus placebo for 2 months. In group 2, patients were treated with diet plus placebo for 1 month, followed by diet plus folic acid $(5 \mathrm{mg} /$ day) plus vitamin B12 $(500 \mu \mathrm{g} /$ day) for another month.

Results: In group 2, folate treatment significantly decreased homocysteine levels by $27.8 \%$ (12.2 \pm 1.2 vs $8.8 \pm 0.7 \mu \mathrm{mol} / \mathrm{l} ; P<0.01)$. A significant decrement was observed for insulin levels $(19.9 \pm 1.7 \mathrm{vs}$ $14.8 \pm 1.6 \mu \mathrm{U} / \mathrm{ml} ; P<0.01$ ) accompanied by a $27 \%$ reduction in the homeostasis model assessment levels. A positive relationship was found between the decrement of homocysteine and insulin levels $(\mathrm{r}=0.60 ; P<0.002)$. In parallel, endothelial dysfunction significantly improved in the treated group, since post-ischemic maximal hyperemic vasodilation increased by $29.8 \%$ and cGMP by $13.6 \%$ while asymmetrical dimethylarginine levels decreased by $21.7 \%$. On the contrary, in group 1 patients, treated with placebo, no changes were shown in any of the variables.

Conclusions: Folate and vitamin B12 treatment improved insulin resistance and endothelial dysfunction, along with decreasing homocysteine levels, in patients with metabolic syndrome, suggesting that folic acid has several beneficial effects on cardiovascular disease risk factors.
\end{abstract}

European Journal of Endocrinology $151483-489$

\section{Introduction}

It has been previously demonstrated that the administration of folic acid in patients with hyperhomocysteinemia leads to lower homocysteine levels by increasing the rate of recycling of homocysteine to methionine (1). In vitro studies have shown that homocysteine can directly damage endothelial cells (2), impairing the release or increasing the inactivation of nitric oxide (NO) (3) and, in turn, decreasing endothelial-dependent vasodilation (4). Conversely, it has been shown that folic acid treatment improves flow-mediated dilation in subjects with hyperhomocysteinemia $(5,6)$. Another effect of homocysteine lies in its capacity to increase the production of asymmetrical dimethylarginine (ADMA), which emerged as an endogenously produced inhibitor of L-arginine, able to cause endothelial cell dysfunction with increased oxidative stress (7).

It is already known that the dysfunctional and uncoupled endothelial cell induced by homocysteine and ADMA becomes a net producer of damaging superoxide $\left(\mathrm{O}_{2}{ }^{-}\right)$instead of generating protective $\mathrm{NO}$, a naturally occurring chain-breaking antioxidant (8). Oxygen reacts with the endothelial NO synthase (eNOS) enzyme in which tetrahydrobiopterin (BH4) cofactor is coupled to $\mathrm{NAD}(\mathrm{P}) \mathrm{H}$ to convert L-arginine to $\mathrm{NO}$ 
and L-citrulline. When this cofactor is oxidized and does not function properly the entire eNOS reaction is uncoupled and the endothelium becomes a net producer of superoxide $\left(\mathrm{O}_{2}{ }^{-}\right)$radicals through the uncoupled $\mathrm{NAD}(\mathrm{P}) \mathrm{H}$ oxidase reaction (9). In addition to being a necessary cofactor, $\mathrm{BH} 4$ also serves as a naturally occurring antioxidant capable of scavenging reactive oxygen species such as $\mathrm{O}_{2}^{-}$and peroxynitrite. A direct effect of folic acid in keeping $\mathrm{BH} 4$ functionally intact to maintain a coupled eNOS reaction has been demonstrated (10). In addition, folic acid was able to prevent NO synthase dysfunction induced by nitrate tolerance in the arterial circulation of healthy subjects (11) and pretreatment with oral folic acid prevented the endothelial dysfunction induced by acute hyperlipidemia following an oral fat load (12).

Controversial data on the association between insulin resistance and plasma homocysteine levels have been reported. In two large epidemiological studies, hyperhomocysteinemia was modestly but significantly associated with insulin levels and insulin resistance $(13,14)$. In addition, several case-control studies (15-20) have shown that insulin levels are significantly related to homocysteine levels in various groups of patients, such as hypertensive patients with type 2 diabetes, obese patients, women with polycystic ovary syndrome and pregnant women with pre-eclampsia. In contrast, Abbasi et al. (21) were unable to confirm such an association in a group of healthy subjects, and two other reports have indicated that an improvement in insulin sensitivity was not accompanied by an amelioration of homocysteine levels $(22,23)$. Whereas a few studies in animals have suggested that insulin affects the activity of the key enzymes of homocysteine metabolism (24), little is known about the relationship between homocysteine and insulin sensitivity in humans.

The possibility that folic acid might also act through an amelioration of insulin sensitivity in patients with metabolic syndrome might help to understand the beneficial effect of this drug in reducing cardiovascular risk factors in this class of patients.

Therefore, the aim of the present study was (a) to study whether a folate and vitamin B12 treatment, aimed at decreasing homocysteine levels, might ameliorate insulin resistance and endothelial dysfunction in patients with metabolic syndrome according to the National Cholesterol Education Program (NCEP)Adult Treatment Panel (ATP)-III criteria (25) and (b) to evaluate whether, under these metabolic conditions, a decrease of homocysteine levels correlates with an amelioration of insulin sensitivity.

\section{Materials and methods}

\section{Subjects}

All subjects gave informed consent for their participation in the study and the local ethics committee approved the protocol. We enrolled 50 patients with the following selection criteria: (a) presence of metabolic syndrome identified as fulfilling the NCEP-ATPIII criteria (25) and (b) the presence of hyperinsulinemia (Table 1). The anti-hypertensive therapy consisted of $\beta$-blockers, Ca antagonists and angiotensin-converting enzyme inhibitors, which were withdrawn 4 days before each test.

\section{Study design}

A double-blind, parallel, identical placebo-drug, randomized study was performed for 2 months. In particular, patients with metabolic syndrome were randomly allocated to two groups. In group 1, patients were treated with diet plus placebo for 2 months. In group 2 , patients were treated for 1 month with diet plus placebo and then for 1 month with diet plus oral folic acid (folic sodic acid, $5 \mathrm{mg} /$ day (Schwarz Pharma, Milan, Italy)) plus vitamin B12 (500 $\mu \mathrm{g} /$ day (Roche, Basel, Switzerland)) administration - subsequently referred as folate treatment - since recently published data have shown that folate and vitamin B12 are more effective in decreasing homocysteine levels than folate alone (26). Every 14 days, patients were reviewed by a dietician to maintain a constant body weight throughout the study and to equalize diet treatment between the two study groups.

At the end of each month of therapy, all subjects were admitted to the Metabolic Unit (part of Diabetology, Endocrinology, Metabolic Disease Unit) in the morning after an overnight fast, and samples were withdrawn after at least $30 \mathrm{~min}$ of resting in the supine position. After this period, basal forearm blood flow and systolic and diastolic blood pressure were measured. Maximal post-ischemic forearm blood flow was evaluated using venous occlusion plethismography techniques, according to Capaldo et al. (27). To measure endothelial independent vasodilation, forearm blood flow was evaluated immediately before and $3 \mathrm{~min}$

Table 1 Anthropometric and metabolic variables after 1 month of placebo therapy in 50 patients with metabolic syndrome (means \pm S.E.M.).

\begin{tabular}{lr}
\hline Gender: males-females & $41-9$ \\
Age (years) & $67.3 \pm 1.2$ \\
Weight $(\mathrm{kg})$ & $79.5 \pm 1.5$ \\
Body mass index $(\mathrm{BMI})\left(\mathrm{kg} / \mathrm{m}^{2}\right)$ & $28.7 \pm 0.6$ \\
Waist circumference $(\mathrm{cm})$ & $125.3 \pm 1.2$ \\
Systolic blood pressure $(\mathrm{mmHg})$ & $164.5 \pm 2.0$ \\
Diastolic blood pressure $(\mathrm{mmHg})$ & $90.7 \pm 1.4$ \\
Fasting glucose $(\mathrm{mmol} / \mathrm{l})$ & $6.3 \pm 0.1$ \\
Fasting insulin $(\mu \mathrm{U} / \mathrm{ml})$ & $19.6 \pm 1.0$ \\
HbA1c $(\%)$ & $5.8 \pm 0.1$ \\
Fasting triglycerides $(\mathrm{mmol} / \mathrm{l})$ & $3.59 \pm 0.14$ \\
Fasting cholesterol $(\mathrm{mmol} / \mathrm{l})$ & $5.77 \pm 0.24$ \\
Fasting HDL cholesterol $(\mathrm{mmol} / \mathrm{l})$ & $1.25 \pm 0.06$ \\
Fasting creatinine $(\mu \mathrm{mol} / \mathrm{l})$ & $75.2 \pm 2.25$
\end{tabular}

HDL, high-density lipoprotein. 
after the administration of isosorbide dinitrate $(0.5 \mathrm{mg})$ (Nitrosorbide, Lusofamarco, Milan, Italy). The coefficient of variation (C.V.) of the test was $4.3 \%$.

To evaluate fasting insulin resistance, the homeostasis model assessment (HOMA) index was used. The following formula was applied (glucose $(\mathrm{mmol} / \mathrm{l}) \times$ insulin $(\mu \mathrm{U} / \mathrm{ml}) / 22.5)(28)$.

\section{Assays}

Plasma glucose was measured with a glucose oxidasebased analyzer (Beckman Glucose Analyzer; Beckman, Fullerton, CA, USA). Serum insulin levels (intra-assay C.V. $3.0 \%$, interassay C.V. $5.0 \%$ ) were assayed with a microparticle enzyme immunoassay (MEIA) (IMX; Abbott Laboratories, Abbott Park, IL, USA). Serum triglyceride, cholesterol, high-density lipoprotein cholesterol and creatinine levels were measured using automated enzymatic spectrophotometric techniques adapted to Cobas Fara II (Roche). cGMP was assayed with an RIA kit (Amersham International plc, Amersham, Bucks, UK). Homocysteine was measured with an MEIA.

ADMA and symmetrical dimethylarginine (SDMA) were extracted from plasma samples using cationexchange Strata SCX $100 \mathrm{mg}$ columns (Phenomenex, Chemtek Analytica, Bologna, Italy) and assayed by high performance liquid chromatography as previously described (29).

Folate and vitamin B12 levels in serum were measured by RIA (DPC dual count solid phase kits; Diagnostic Products Corporation, Los Angeles, CA, USA).

\section{Statistical analysis}

All data are given as means \pm S.E.M. Comparisons within groups were performed by Student's t-test for paired data. Comparisons among groups were performed by
ANOVA followed by the Scheffe F test when appropriate. Pearson and Spearman correlation coefficients were also used, where appropriate. A two-tailed probability level $<0.05$ was considered statistically significant. Multiple regression analysis was performed with changes in insulin levels after folate or placebo therapy as the dependent variable and all other parameters as independent variables. In addition, a similar analysis was performed using changes in maximal postischemic forearm blood flow after folate or placebo therapy as the dependent variable and all other parameters as independent variables.

\section{Results}

In Tables 2 and 3 are reported all the metabolic and endothelial variables under evaluation, before and after folate or placebo treatment. In group 2, folate treatment decreased homocysteine levels by $27.8 \%$ $(12.2 \pm 1.2$ to $8.8 \pm 0.7 \mu \mathrm{mol} / \mathrm{l} ; P<0.01)$ and ADMA levels by $21.7 \%(0.92 \pm 0.08$ to $0.72 \pm 0.05 \mu \mathrm{mol} / \mathrm{ml}$; $P<0.001)$. Interestingly, a similar percentage decrement was observed in insulin levels $(25.6 \%$, from $19.9 \pm 1.7$ to $14.8 \pm 1.6 \mu \mathrm{U} / \mathrm{ml} ; \quad P<0.01)$ and in HOMA levels, the index of fasting insulin resistance (27\%, from $5.48 \pm 0.43$ to $4.00 \pm 0.43 ; P<0.01)$. A significant improvement in endothelial function was achieved, as demonstrated by an increment in postischemic maximal hyperemic vasodilation by $29.8 \%$ (from $18.1 \pm 1.3$ to $23.5 \pm 1.6 \mathrm{ml} / 100 \mathrm{ml}$ forearm per min; $P<0.001$ ), while endothelial-independent vasodilation remained unchanged. A possible involvement of the NO pathway was suggested by the fact that increased cGMP levels, the second messenger of NO, were shown (from $2.16 \pm 0.18$ to $2.96 \pm 0.27 \mathrm{pmol} / \mathrm{ml}$; $P<0.01)$. In parallel, a slight but significant decrease in systolic blood pressure was also demonstrated. On the contrary, no changes were demonstrated in all these parameters in group 1.

Table 2 Changes in anthropometric and metabolic variables in patients with metabolic syndrome after 2 months of placebo therapy (group 1; 25 patients) or after 1 month of placebo followed by 1 month of folate therapy (group 2; 25 patients). Values are mean \pm S.E.M.

\begin{tabular}{|c|c|c|c|c|c|c|}
\hline & \multicolumn{3}{|c|}{ Group 1 (21 male/4 female) } & \multicolumn{3}{|c|}{ Group 2 (20 male/5 female) } \\
\hline & $\begin{array}{l}\text { Placebo } \\
\text { 1st month }\end{array}$ & $\begin{array}{c}\text { Placebo } \\
\text { 2nd month }\end{array}$ & Difference & $\begin{array}{l}\text { Placebo } \\
\text { 1st month }\end{array}$ & $\begin{array}{c}\text { Folate } \\
\text { 2nd month }\end{array}$ & Difference \\
\hline Body weight (kg) & $79.1 \pm 2.4$ & $78.8 \pm 2.3$ & $-0.32 \pm 0.43$ & $79.8 \pm 1.8$ & $78.7 \pm 2.0$ & $-1.10 \pm 1.23$ \\
\hline $\mathrm{BMI}\left(\mathrm{kg} / \mathrm{m}^{2}\right)$ & $28.1 \pm 0.7$ & $28.0 \pm 0.6$ & $-0.1 \pm 0.1$ & $29.4 \pm 0.8$ & $28.7 \pm 0.7$ & $-0.7 \pm 0.3$ \\
\hline $\begin{array}{l}\text { Systolic blood } \\
\text { pressure }(\mathrm{mmHg})\end{array}$ & $165 \pm 2$ & $165 \pm 3$ & $0 \pm 2$ & $164 \pm 4$ & $154 \pm 2 \dagger$ & $-10 \pm 3^{*}$ \\
\hline $\begin{array}{l}\text { Diastolic blood } \\
\text { pressure }(\mathrm{mmHg})\end{array}$ & $92 \pm 2$ & $93 \pm 2$ & $1 \pm 1$ & $89 \pm 2$ & $85 \pm 2$ & $-4 \pm 2$ \\
\hline Fasting glucose $(\mathrm{mmol} / \mathrm{l})$ & $6.24 \pm 0.08$ & $6.16 \pm 0.08$ & $-0.08 \pm 0.10$ & $6.21 \pm 0.18$ & $5.98 \pm 0.16$ & $-0.23 \pm 0.12$ \\
\hline Fasting insulin $(\mu \mathrm{U} / \mathrm{ml})$ & $19.3 \pm 1.3$ & $19.0 \pm 1.13$ & $-0.4 \pm 1.0$ & $19.9 \pm 1.7$ & $14.8 \pm 1.6 \ddagger$ & $-5.72 \pm 1.10^{*}$ \\
\hline HOMA & $5.38 \pm 0.38$ & $5.21 \pm 0.33$ & $-0.17 \pm 0.32$ & $5.48 \pm 0.43$ & $4.00 \pm 0.43 \ddagger$ & $-1.48 \pm 0.30 *$ \\
\hline $\begin{array}{l}\text { Fasting triglycerides } \\
\qquad(\mathrm{mmol} / \mathrm{l})\end{array}$ & $3.75 \pm 0.18$ & $3.56 \pm 0.22$ & $-0.18 \pm 0.21$ & $3.43 \pm 0.23$ & $2.82 \pm 0.51 \dagger$ & $-0.61 \pm 0.18$ \\
\hline
\end{tabular}

${ }^{\star} P<0.01$ vs treatment with placebo; $\uparrow P<0.05$ vs placebo (1st month); $¥ P<0.01$ vs placebo (1st month). 
Table 3 Changes in endothelial variables in patients with metabolic syndrome after 2 months of placebo therapy (group 1;25 patients) or after 1 month of placebo followed by 1 month of folate therapy (group 2; 25 patients). Values are mean \pm S.E.M.

\begin{tabular}{|c|c|c|c|c|c|c|}
\hline & \multicolumn{3}{|c|}{ Group 1 (21 male/4 female) } & \multicolumn{3}{|c|}{ Group 2 (20 male/5 female) } \\
\hline & $\begin{array}{l}\text { Placebo } \\
\text { 1st month }\end{array}$ & $\begin{array}{l}\text { Placebo } \\
\text { 2nd month }\end{array}$ & Difference & $\begin{array}{l}\text { Placebo } \\
\text { 1st month }\end{array}$ & $\begin{array}{l}\text { Folate } \\
\text { 2nd month }\end{array}$ & Difference \\
\hline Folate (ng/ml) & $13.2 \pm 0.7$ & $13.4 \pm 0.8$ & $0.3 \pm 0.7$ & $12.4 \pm 1.0$ & $29.2 \pm 2.6$ & $16.9 \pm 2.5 \dagger$ \\
\hline Vitamin B12 (pg/ml) & $293 \pm 17$ & $294 \pm 15$ & $0 \pm 14$ & $302 \pm 17$ & $489 \pm 24 \eta$ & $186 \pm 18 \dagger$ \\
\hline Homocysteine $(\mu \mathrm{mol} / \mathrm{l})$ & $11.0 \pm 0.7$ & $10.8 \pm 0.3$ & $-0.2 \pm 0.6$ & $12.2 \pm 1.2$ & $8.8 \pm 0.79$ & $-3.4 \pm 0.8^{\star}$ \\
\hline cGMP (pmol/mli) & $2.26 \pm 0.14$ & $2.33 \pm 0.14$ & $0.10 \pm 0.20$ & $2.16 \pm 0.18$ & $2.96 \pm 0.27 \ddagger$ & $0.80 \pm 0.20 *$ \\
\hline ADMA $(\mu \mathrm{mol} / \mathrm{ml})$ & $0.95 \pm 0.08$ & $0.93 \pm 0.07$ & $-0.02 \pm 0.02$ & $0.92 \pm 0.08$ & $0.72 \pm 0.05$ & $-0.21 \pm 0.05^{\star}$ \\
\hline SDMA $(\mu \mathrm{mol} / \mathrm{ml})$ & $0.61 \pm 0.05$ & $0.62 \pm 1.13$ & $0.01 \pm 0.08$ & $0.63 \pm 0.06$ & $0.61 \pm 0.05$ & $-0.02 \pm 0.04$ \\
\hline $\begin{array}{l}\text { Basal forearm } \\
\text { blood flow }\end{array}$ & $2.68 \pm 0.16$ & $2.50 \pm 0.14$ & $-0.18 \pm 0.15$ & $2.51 \pm 0.16$ & $2.65 \pm 0.16$ & $0.14 \pm 0.17$ \\
\hline $\begin{array}{l}\text { Maximum post-ischemic } \\
\text { forearm blood flow }\end{array}$ & $19.2 \pm 1.3$ & $16.7 \pm 1.0$ & $-2.5 \pm 1.2$ & $18.1 \pm 1.3$ & $23.5 \pm 1.6 \ddagger$ & $5.4 \pm 1.5 \dagger$ \\
\hline $\begin{array}{l}\text { Endothelial-independent } \\
\text { vasodilation in forearm } \\
\text { blood flow }^{\mathrm{a}}\end{array}$ & $5.26 \pm 0.38$ & $5.31 \pm 0.34$ & $-0.05 \pm 1.8$ & $5.34 \pm 0.30$ & $5.39 \pm 0.30$ & $-0.05 \pm 0.20$ \\
\hline
\end{tabular}

${ }^{\mathrm{a}} \mathrm{ml} / 100 \mathrm{ml}$ forearm per min.

${ }^{\star} P<0.01$ vs placebo; $\uparrow P<0.001$ vs placebo; $\ddagger P<0.05$ vs placebo (1st month); $\uparrow P<0.001$ vs placebo (1st month).

In an attempt to better understand the effects of folate treatment on the metabolic and endothelial variables, we analyzed the differences in their values at the end of the placebo or the folate treatment compared with those at the start of both treatments in terms of net increment or decrement, and the data are reported in Tables 2 and 3 under the columns labeled 'Difference'. As expected, in group 2, along with a significant decrement in homocysteine $(-0.2 \pm 0.6$ vs $-3.4 \pm 0.8$ $\mu \mathrm{mol} / \mathrm{l} ; P<0.01)$ and ADMA levels $(-0.02 \pm 0.02$ vs $-0.21 \pm 0.05 \mu \mathrm{mol} / \mathrm{ml} ; P<0.001)$, there was a significant decrement in insulin $(-0.4 \pm 1.0 \mathrm{vs}-5.72 \pm 1.10$ $\mu \mathrm{U} / \mathrm{ml} ; P<0.01)$, HOMA $(-0.17 \pm 0.32$ vs $-1.48 \pm$ $0.30 ; P<0.01)$ and systolic blood pressure $(0 \pm 2$ vs $-10 \pm 3 \mathrm{mmHg} ; P<0.01$ ) (Table 2). On the contrary, significant increments in cGMP levels $(0.10 \pm 0.20$ vs $0.80 \pm 0.20 \mathrm{pmol} / \mathrm{ml} ; \quad P<0.01)$ and post-ischemic maximal hyperemic vasodilation $(-2.5 \pm 1.2$ vs $5.4 \pm 1.56 \mathrm{ml} / 100 \mathrm{ml}$ forearm per $\mathrm{min} ; \quad P<0.001)$ were observed (Table 3$)$.

Pooling all the data together, homocysteine levels were positively correlated with insulin $(\mathrm{r}=0.31$, $P<0.002)$, HOMA $(r=0.29, \quad P<0.005) \quad$ and triglyceride $(r=0.24, P<0.02)$ levels. Finally, ADMA levels were negatively correlated with post-ischemic maximal hyperemic vasodilation $(\mathrm{r}=-0.27$, $P<0.01)$. In addition, cGMP levels were positively correlated with post-ischemic maximal hyperemic vasodilation $(\mathrm{r}=0.27, P<0.01)$ and negatively correlated with insulin $(r=-0.33, \quad P<0.0001)$ and HOMA $(\mathrm{r}=-0.32, P<0.0002)$ levels. In group 2 , the analysis of the difference between placebo vs folate treatment showed that the decrement in homocysteine levels was significantly correlated with the decrement in insulin levels ( $r=0.60, P<0.002$; Fig. 1$)$.

In a multiple regression analysis, changes in homocysteine levels independently correlated with changes

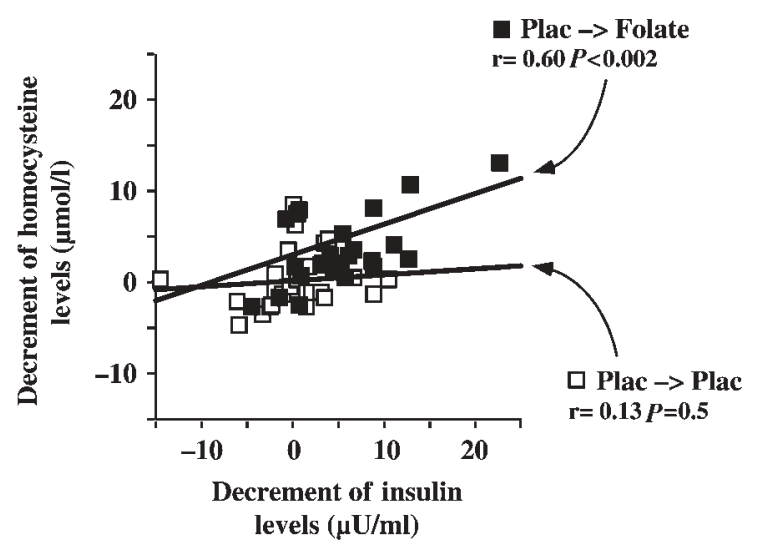

Figure 1 Relationship between the decrement in homocysteine and the decrement in insulin levels during folate $(\boldsymbol{\square})$ and placebo (Plac) treatment ( $\square$ ). A positive relationship was found between the two parameters during folate treatment while no relationship was found during placebo administration.

in insulin levels $(P<0.002$; data not shown). In addition, changes in maximal post-ischemic forearm blood flow were independently correlated with changes in cGMP $(P<0.005$; data not shown $)$ and ADMA levels $(P<0.01$; data not shown $)$.

\section{Discussion}

The present study has shown, for the first time, that a prolonged folate treatment decreased not only homocysteine levels but also reduced insulin levels, improving insulin resistance in patients with metabolic syndrome. Furthermore, it improved endothelial function as demonstrated by an increment in cGMP levels and maximal post-ischemic forearm blood flow and decreased ADMA levels. Our work seems to strengthen 
the evidence that folic acid treatment has various beneficial effects in reducing the risk factors of cardiovascular disease, as recently reviewed (30).

The most interesting result of the study relates to the relationship between the decrement of homocysteine levels by folate treatment and the reduction of insulin levels, with an amelioration of insulin sensitivity in severe insulin-resistant patients, adding new data on the controversial relationship between insulin and homocysteine.

Also, in our study, the correlation coefficient between insulin and homocysteine levels was $r=0.60$, with results similar to those reported in three studies in both rats and humans (18). We were not able to add any new insights on the possibility that insulin modulates homocysteine levels, as suggested in rats (24), or whether it is homocysteine that is able to modulate insulin levels. An action of homocysteine on the insulin secretory pathway was demonstrated by Najib \& Sanchez-Margalet (31), who found that homocysteine thiolactone, the active form of homocysteine, inhibited the insulin-stimulated tyrosine phosphorylation of insulin receptor $\beta$-subunit and its substrates insulin receptor substrate-1 and p60-70 in rat hepatoma cells (31). In addition, they showed that homocysteine thiolactone decreased the p85 regulatory subunit of phosphatidylinositol 3-kinase activity, inducing a reduction in insulin-stimulated glycogen synthesis (31). In that study, the effects of $100 \mathrm{nM}$ insulin were completely blocked by $50 \mu \mathrm{M}$ homocysteine thiolactone, suggesting that, in this in vitro study, $1 \mu \mathrm{M}$ homocysteine thiolactone inhibited $\sim 300 \mu \mathrm{U} / \mathrm{ml}$ insulin, partly explaining the result of our in vivo study in which a $3.4 \mu \mathrm{mol} / \mathrm{l}$ decrement of homocysteine levels was associated with a decrease in circulating insulin levels of $5 \mu \mathrm{U} / \mathrm{ml}$, but this important issue deserves further investigation.

However, it must be underlined that the effect of folate treatment in reducing insulin resistance is very important since our group previously demonstrated that insulin resistance and decreased NO release after an oral glucose tolerance test, as an index of endothelial dysfunction, are independent predictors of restenosis after stent implantation in patients with cardiovascular disease (32). Thus, a treatment able to ameliorate both insulin resistance and endothelial dysfunction might be very helpful in the treatment of cardiovascular disease in patients with metabolic syndrome.

A potential bias of our study might be due to the confounding effect of prolonged diet therapy on insulin sensitivity in the patients treated with folate treatment. However, in placebo-treated patients, no significant effect of prolonged diet treatment was demonstrated. In addition, body weight did not change during the 6 months before and throughout the study, and reviews by a dietitian were performed every 2 weeks to maintain a constant diet during all study periods, both placebo and folate treatment. In addition, the significant increment in serum folate and vitamin B12 levels suggests a good compliance of patients to treatment. All these points made us trust the true effect of folate treatment on insulin sensitivity.

Another possible confounding factor could be related to genetic determinants of homocysteine metabolism causing different effects of folate therapy on insulin resistance. At present only two studies have evaluated the effects the of C677T polymorphism of 5,10-methylentetrahydrofolate reductase in subjects with insulin resistance and no significant correlations were found between this polymorphism and homocysteine levels and/or common features of insulin resistance $(33,34)$.

The data from the present study underline the effects of folate treatment in improving endothelial function as suggested by the improvement of maximal postischemic vasodilation, associated with a reduction in systolic blood pressure. These confirm previous results on the effects of folate on vascular endothelial function, as recently reviewed (30). In addition, we were able to find a $20 \%$ decrease in ADMA levels after a month of folate treatment, a figure in agreement with previous data reporting a $30 \%$ decrease in ADMA after 3 months of therapy with metformin and peroxisome proliferator-activated receptor $\gamma(\operatorname{PPAR} \gamma)$ agonists $(35,36)$. The importance of folate treatment in reducing ADMA levels in hyperhomocysteinemic patients has also been reported by Holven et al. (37). On the contrary, different results have been reported by Sydow et al. (38), who found that treatment with $10 \mathrm{mg}$ folate and $200 \mu \mathrm{g}$ vitamin B2 daily for 8 weeks, although it significantly decreased homocysteine levels, was unable to influence both endothelial vasodilation and ADMA levels. One possible explanation is related to the different degree of atherosclerosis present in the three studies (18). In fact, in the present study and in that of Holven et al. (37), patients were affected by metabolic syndrome and hyperhomocysteinemia in the absence of peripheral vascular disease while in Sydow et al. (38) patients had severe peripheral arterial occlusive disease. All in all, these results strongly underline the importance of starting folate therapy as early as possible in these patients, when endothelial dysfunction could be still reversible.

Previous studies have demonstrated that homocysteine could regulate ADMA metabolism by inhibiting dimethyl arginine dimethylaminohydrolase (DDAH) activity. Stühlinger et al. (39) suggested that homocysteine, binding DDAH, could form mixed disulfides capable of blocking ADMA binding (39). This mechanism might explain why hyperhomocysteinemia could lead to an increase in ADMA levels by reducing NO elaboration from endothelial cells. Another possible mechanism explaining the effects of homocysteine in increasing ADMA levels has been proposed by Boger et al. (40) studying human endothelial cells in 
the presence of a high concentration of homocysteine. They postulated that an increase in methionine availability could result in increased ADMA formation (40). In accordance with Stühlinger et al. (39), the present study, providing evidence that folate treatment decreases homocysteine levels and in turn induces a significant decrement in ADMA but not SDMA levels, seems to support the hypothesis that ADMA levels are regulated by alterations in DDAH activity.

An effect of folate treatment mediated by an NO pathway seems to be strengthened by the increased circulating cGMP levels found in the present study in patients with metabolic syndrome after 1 month of folate treatment. It is interesting to note that circulating cGMP levels before folate therapy were similar to those found in type 2 diabetic patients while, after folate therapy, cGMP was significantly increased to levels found in normal subjects (41). To our knowledge, these data with regard to the effects of folate on cGMP levels have never been reported in humans but are in accordance with previous results in rats, demonstrating that ischemia-induced angiogenesis was rescued by oral folate via an NO-dependent mechanism (42). In particular, the authors found increased tissue nitric oxide and, in turn, cGMP concentrations which correlated with increased serum folate levels, supporting our data of a folate-dependent increase in cGMP levels, a new mechanism of action of folate treatment.

On the other hand, folate treatment could improve endothelium-dependent vasodilation by other metabolic pathways. First, folic acid reduces homocysteine levels by increasing the rate of recycling of homocysteine to methionine (1), preventing homocysteineinduced oxidative stress and consequently endothelial injury. Secondly, folic acid decreases the formation of $\mathrm{NO}_{2}^{-}$anions and peroxynitrite induced by high homocysteine concentrations restoring the NO response to bradykinin and L-arginine. In fact, Stroes et al. (43) demonstrated that in the presence of decreased availability of tetrahydrobiopterin, an essential cofactor of eNOS, there was a shift in the balance between the precursors of NO and oxygen free radicals by the enzyme. Thirdly, folic acid could improve endothelial function per se as recently shown by Doshi et al. (44), who found that acute oral administration of $5 \mathrm{mg}$ folate significantly increased flow-mediated dilation and that this effect was independent of changes in homocysteine levels. However, data in the present study suggest that folate acts mainly through the different pathways previously proposed, while the direct effects of folate probably have only a secondary role.

In conclusion, in patients with metabolic syndrome, folate treatment improved insulin resistance and endothelial dysfunction, along with decreasing homocysteine and ADMA levels, suggesting that folic acid may have several beneficial effects on cardiovascular disease risk factors.

\section{Acknowledgement}

This work was supported in part by a grant from the Ministry of Health (ICS 030.6/RFO0-49).

\section{References}

1 Mayer EL, Jacobsen DW \& Robinson K. Homocysteine and coronary atherosclerosis. Journal of the American College of Cardiology $199627517-527$

2 Wall RT, Harlan JM, Harker LA \& Striker GE. Homocysteineinduced endothelial cell injury in vitro: a model for the study of vascular injury. Thrombosis Research 198018 113-121.

3 Stamler JS, Osborne JA, Jaraki O, Rabbani LE, Mullins M, Singel D \& Loscalzo J. Adverse vascular effects of homocysteine are modulated by endothelium-derived relaxing factor and related oxides of nitrogen. Journal of Clinical Investigation $1993 \mathbf{9 1}$ 308-318.

4 Tawakol A, Omland T, Gerhard M, Wu J \& Creager MA. Hyperhomocyst(e)inemia is associated with impaired endotheliumdependent vasodilation in humans. Circulation $1997 \mathbf{9 5}$ 1119-1121.

5 Bellamy MF, McDowell IF, Ramsey MW, Brownlee M, Newcombe RG \& Lewis MJ. Oral folate enhances endothelial function in hyperhomocysteinaemic subjects. European Journal of Clinical Investigation $199929659-662$.

6 Woo KS, Chook P, Lolin YI, Sanderson JE, Metreweli C \& Celermajer DS. Folic acid improves arterial endothelial function in adults with hyperhomocysteinemia. Journal of the American College of Cardiology $1999342002-2006$.

7 Vallance P, Leone A, Calver A, Collier J \& Moncada S. Endogenous dimethylarginine as an inhibitor of nitric oxide synthesis. Journal of Cardiovascular Pharmacology 199220 S60-S62.

8 Heitzer T, Schlinzig T, Krohn K, Meinertz T \& Munzel T. Endothelial dysfunction, oxidative stress, and risk of cardiovascular events in patients with coronary artery disease. Circulation $20011042673-2678$.

9 Beckman JS \& Koppenol WH. Nitric oxide, superoxide, and peroxynitrite: the good, the bad, and ugly. American Journal of Physiology 1996271 C1424-C1433.

10 Stroes ES, van Faassen EE, Yo M, Martasek P, Boer P, Govers R \& Rabelink TJ. Folic acid reverts dysfunction of endothelial nitric oxide synthase. Circulation Research 200086 1129-1134.

11 Gori T, Burnstein JM, Ahmed S, Miner SE, Al Hesayen A, Kelly S \& Parker JD. Folic acid prevents nitroglycerin-induced nitric oxide synthase dysfunction and nitrate tolerance: a human in vivo study. Circulation $2001 \mathbf{1 0 4} 1119-1123$.

12 Wilmink HW, Stroes ES, Erkelens WD, Gerritsen WB, Wever R, Banga JD \& Rabelink TJ. Influence of folic acid on postprandial endothelial dysfunction. Arteriosclerosis Thrombosis and Vascular Biology 200020 185-188.

13 Meigs JB, Jacques PF, Selhub J, Singer DE, Nathan DM, Rifai N, D'Agostino RB Sr, Wilson PW \& the Framingham Offspring Study. Fasting plasma homocysteine levels in the insulin resistance syndrome. Diabetes Care 200124 1403-1410.

14 Gillum R. Distribution of serum total homocysteine and its association with diabetes and cardiovascular risk factors of the insulin resistance syndrome in Mexican American men: the Third National Health and Nutrition Examination Survey. Nutrition Journal 20032 6-13.

15 Giltay EJ, Hoogeveen EK, Elbers JMH, Gooren LJG, Asscheman H \& Stehouwer CDA. Insulin resistance is associated with elevated plasma total homocysteine levels in healthy, non-obese subjects. Atherosclerosis $1998139197-198$.

16 Emoto M, Kanda H, Shoji T, Kawagishi T, Komatsu M, Mori K, Tahara H, Ishimura E, Inaba M, Okuno Y \& Nishizawa Y. Impact of insulin resistance and nephropathy on homocysteine in type 2 diabetes. Diabetes Care 200124 533-538. 
17 Fonseca VA, Fink LM \& Kern PA. Insulin sensitivity and plasma homocysteine concentrations in non diabetic obese and normal weight subjects. Atherosclerosis $2003 \mathbf{1 6 7} 105-109$.

18 Oron-Herman M, Rosenthal T \& Sela BA. Hyperhomocysteinemia as a component of syndrome X. Metabolism $2003 \mathbf{5 2}$ 1491-1495.

19 Schachter M, Raziel A, Friedler S, Strassburger D, Bern O \& Ron-El R. Insulin resistance in patients with polycystic ovary syndrome is associated with elevated plasma homocysteine. Human Reproduction $2003 \mathbf{1 8} 721-727$.

20 Laivuori H, Kaaja R, Turpeinen U, Viinikka L \& Ylikorkala O. Plasma homocysteine levels elevated and inversely related to insulin sensitivity in preeclampsia. Obstetrics and Gynecology $199993489-493$.

21 Abbasi F, Facchini F, Humphreys MH \& Reaven GM. Plasma homocysteine concentrations in healthy volunteers are not related to differences in insulin mediated glucose disposal. Atherosclerosis $1999146175-178$.

22 Wulfelle MG, Kooy A, Lehert P, Bets D, Ogterop JC, Borger van de Burg B, Donker AJ \& Stehouwer CD. Effects of short-term treatment with metformin on serum concentrations of homocysteine, folate and vitamin B12 in type 2 diabetes mellitus: a randomized, placebo-controlled trial. Journal of Internal Medicine $2003 \mathbf{2 5 4}$ 455-463.

23 Pouwels MJ, Den Heijer M, Blom HJ, Tack CJ \& Hermus AR. Improved insulin sensitivity and metabolic control in type 2 diabetes does not influence plasma homocysteine. Diabetes Care $2003261637-1639$.

24 Gursu MF, Baydas G, Cikim G \& Canatan H. Insulin increases homocysteine levels in a dose dependent manner in diabetic rats. Archives of Medical Research 200233 305-307.

25 Expert Panel on Detection Evaluation and Treatment of High Blood Cholesterol in Adults. Executive summary of the third report of the National Cholesterol Education Program (NCEP) Expert Panel on Detection, Evaluation and Treatment of high blood cholesterol in Adults (Adult Treatment Panel III). Journal of the American Medical Association 2001285 2486-2497.

26 Quinlivan EP, McPartlin J, McNulty H, Ward M, Strain JJ, Weir DG \& Scott JM. Importance of both folic acid and vitamin B12 in reduction of risk of vascular disease. Lancet $2002359227-228$.

27 Capaldo B, Guardasole V, Pardo F, Matarazzo M, Di Rella F, Numis F, Merola B, Longobardi S \& Sacca L. Abnormal vascular reactivity in growth hormone deficiency. Circulation 2001103 520-524.

28 Matthews DR, Hosker JP, Rudenski AS, Naylor BA, Treacher DF \& Turner RC. Homeostasis model assessment: insulin resistance and beta-cell function from fasting plasma glucose and insulin concentration in man. Diabetologia $1985 \mathbf{2 8} 412-419$.

29 Piatti PM, Fragasso G, Monti LD, Setola E, Lucotti P, Fermo I, Paroni R, Galluccio E, Pozza G, Chierchia S \& Margonato A. Acute intravenous L-arginine infusion decreases endothelin-1 levels and improves endothelial function in patients with angina pectoris and normal coronary arteriograms. Circulation 2003 $107429-436$.

30 Moat SJ, Lang D, McDowell IFW, Clarke ZL, Madhavan AK, Lewis MJ \& Goodfellow J. Folate, homocysteine, endothelial function and cardiovascular disease. Journal of Nutritional Biochemistry $20041564-79$.

31 Najib S \& Sanchez-Margalet V. Homocysteine thiolactone inhibits insulin signaling, and glutathione has a protective effect. Journal of Molecular Endocrinology 200127 85-91.

32 Piatti PM, Di Mario C, Monti LD, Fragasso G, Sgura F, Caumo A, Setola E, Lucotti P, Galluccio E, Ronchi C, Origgi A, Zavaroni I,
Margonato A \& Colombo A. Association of insulin resistance, hyperinsulinemia, and impaired nitric oxide release with in-stent restenosis in patients undergoing coronary stenting. Circulation 2003108 2074-2081.

33 Orio F Jr, Palomba S, Di Biase S, Colao A, Tauchmanova L, Savastano S, Labella D, Russo T, Zullo F \& Lombardi G. Homocysteine levels and C677T polymorphism of methylenetetrahydrofolate reductase in women with polycystic ovary syndrome. Journal of Clinical Endocrinology and Metabolism 2003 88 673-679.

34 Gallistl S, Sudi K, Mangge H, Erwa W \& Borkenstein M. Insulin is an independent correlate of plasma homocysteine levels in obese children and adolescents. Diabetes Care 200023 $1348-1352$.

35 Stühlinger MC, Abbasi F, Chu JW, Lamendola C, McLaughlin TL, Cooke JP, Reaven GM \& Tsao PS. Relationship between insulin resistance and an endogenous nitric oxide synthase inhibitor. JAMA $2002 \mathbf{2 8 7} 1420-1426$.

36 Asagami T, Abbasi F, Stühlinger M, Lamendola C, McLaughin T, Cooke JP, Reaven GM \& Tsao PS. Metformin treatment lowers asymmetric dimethylarginine concentration in patients with type 2 diabetes. Metabolism $200251843-846$.

37 Holven KB, Haugstad TS, Holm T, Aukrust P, Ose L \& Nenseter MS. Folic acid treatment reduces elevated plasma levels of asymmetric dimethylarginine in hyperhomocysteinaemic subjects. British Journal of Nutrition $2003 \mathbf{8 9} 359-363$.

38 Sydow K, Schwedhelm E, Arakawa N, Bode-Boger SM, Tsikas D, Hornig B, Frolich JC \& Boger RH. ADMA and oxidative stress are responsible for endothelial dysfunction in hyperhomocyst(e)inemia: effects of L-arginine and B vitamins. Cardiovascular Research $200357244-252$.

39 Stühlinger M, Tsao PS, Her JH, Kimoto M. Balint RF \& Cooke JP Homocysteine impairs the nitric oxide synthase pathway. Role of asymmetric dimethylarginine. Circulation $2001 \quad \mathbf{1 0 4}$ 2569-2575.

40 Boger RH, Sydow K, Borlak J, Thum T, Lenzen H, Schubert B, Tsikas D \& Bode-Boger SM. LDL cholesterol upregulates synthesis of asymmetrical dimethylarginine in human endothelial cells. Circulation Research 200087 99-105.

41 Piatti PM, Monti LD, Valsecchi G, Magni E, Setola E, Marchesi F Galli-Kienle M, Pozza G \& Alberti KG. Long term oral L-arginine administration improves peripheral and hepatic insulin sensitivity in type 2 diabetic patients. Diabetes Care 200124 875-880.

42 Sasaki K, Duan J, Murohara T, Ikeda H, Shintani S, Shimada T, Akita T, Egami K \& Imaizumi T. Rescue of hypercholesterolemia-related impairment of angiogenesis by oral folate supplementation. Journal of the American College of Cardiology $2003 \mathbf{4 2}$ 364-372.

43 Stroes E, Kastelein J, Cosentino F, Erkelens W, Wever R, Koomans H, Luscher T \& Rabelink T. Tetrahydrobiopterin restores endothelial function in hypercholesterolemia. Journal of Clinical Investigation $19979941-46$.

44 Doshi SN, McDowell IF, Moat SJ, Payne N, Durrant HJ, Lewis MJ \& Goodfellow J. Folic acid improves endothelial function in coronary artery disease via mechanisms largely independent of homocysteine lowering. Circulation $200210522-26$.

Received 2 April 2004

Accepted 12 July 2004 